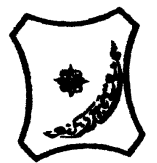

Bayero Journal of Pure and Applied Sciences, 5(1): 139 - 148

Received: December 2011

Accepted: April 2012

ISSN $2006-6996$

\title{
VEGETATION EFFECTS ON PEDOGENETIC FORMS OF IRON AND ALUMINIUM AND MINERALOGICAL PROPERTIES OF BASALTIC SOILS IN THE SOUTHERN GUINEA SAVANNA OF NIGERIA
}

\author{
Samndi, A. M.
}

Department of Soil Science Faculty of Agriculture Bayero University Kano Nigeria. samndiayuba@yahoo.com.

\section{ABSTRACT}

This study investigates the effects of vegetation particularly fast growing exotic species like Tectona grandis on the Newer Basalt of the Jos Plateau. In particular it determines the effects exotic tree species have on the pedogenetic forms of Fe and Al and mineralogical properties of the basaltic soils age. Soil samples were determined at the depth of $0-30 \mathrm{~cm}$ and $30-60 \mathrm{~cm}$ under plantation of four different ages and subjected to standard laboratory analysis. The citrate bicarbonate dithionite (CBD) extractable Fe and Al slightly decreased with aging plantation, which was ascribed to the inhibitory effects of organic matter on the crystallization of Fe and Al. Similarly the active Fe value was less than unity, which implied increased crystalline forms of Fe and $A /$ oxides are as a result of weathering intensity. Mineralogical results indicated that the soils under the fallow and 11 year old plantation had the dominance of magnetites, while those under 21 year old plantation had mixed mineralogy, consisting of magnetites, biotites and montmorillonites. The older plantations (31 and 36 year old) were dominated by kaolinites and traces of haematites and goethites. The trend suggested an increased level of pedogenesis with aging plantations. Increase in crystalline forms of Fe and Al, kaolinites, traces of haematite and goethite concludes that Tectona grandis deteriorates soil properties over time.

Keywords: Vegetation, pedogenic Fe, Al, mineralogy, basaltic soil properties

\section{INTRODUCTION}

Vegetation plays an important role in soil formation and development as it accelerates local weathering (Phillips et al., 2008), thus the effect of trees on the soil chemical properties is a function of series of factors such as nutrient uptake, leachates from tree bark, foliage, roots and organic acids from decomposing litters. Dead plant, on decomposition release water - soluble compounds which play an important role in cycling of metals, decomposition and transformation of clay minerals (Huang and Keller 1970, Schnitzer and Kodama 1976). Humic and fulvic acids produced as a result of litter decomposition are classified as naturally occurring poly electrolytes capable of attacking and degrading soil minerals. Tan (1980) noted that at $\mathrm{pH} 7.0$ fulvic acids are capable of dissolving small amounts of Al from $\mathrm{K}$ - feldspars, biotites and muscovite. Similarly Schnitzer and Kodama (1976) reported a massive dissolution of Si, $\mathrm{Al}, \mathrm{Mg}, \mathrm{Fe}$ and $\mathrm{K}$ from mica mineral by fulvic acid. Direct relationship between protocatechuic acid released from plant litters and $\mathrm{Fe}$ and $\mathrm{Al}$ dissolved from the soil was reported by Andrew and John (1988). They stated that polyphenolic content was highly correlated dissolved Fe $(r=0.80)$ and $\mathrm{Al}(r=$ 0.94). Balagopalan and Rugmini (1989) studied the effects of Tectona grandis plantation on soil characteristics and reported high values of $\mathrm{Fe}_{2} \mathrm{O}_{3}$ and $\mathrm{Al}_{2} \mathrm{O}_{3}$ which were attributed to the effects of hydrolytic breakdown of soil minerals and their interaction with humic constituents. High $\mathrm{Fe}_{d}$ and $\mathrm{Al}_{d}$ with low $\mathrm{Fe}_{\mathrm{o}}$ $\mathrm{Fe}_{2} \mathrm{O}_{3}$ and $\mathrm{Al}_{2} \mathrm{O}_{3}$ were reported under tea plantation by Alekseeva et al.(2010). After 40 to 50 years establishment of Laurophyllous species. Zanellis et al.
(2007) observed partial changes in Fe and Al content, while $\mathrm{Fe}_{\mathrm{o}} / \mathrm{Fe}_{\mathrm{d}}$ ratio was high which was ascribed to intensive weathering. The amount and nature of amorphous and crystalline inorganic oxides of $\mathrm{Fe}$ and Al greatly influence soil physical and chemical properties, their distribution in soils could be used to determine soil forming processes, direction, extent of pedogenic processes and soil age (Blume and Schwertmann, 1969; Mckeaque et al. 1971; Alexander 1974).

The direct influence of plants on soil properties is initiated through nutrient uptake to meet their nutritional needs. This involves the ability of plant roots to exchange $\mathrm{H}_{3} \mathrm{O}$ ions from the roots with metal ions from the soil minerals. Courchesne and Gobran (1997) corroborated the pedogenic significance of rhizosphere and the role of roots as dynamic weathering agents. Spyrikadis et al. (1967) reported that hydrolysis of alumino - silica minerals is as a result of the replacement of metal cations by $\mathrm{H}_{3} \mathrm{O}$ ions with the resultant disarrangement of the crystal lattice structure and the release of $\mathrm{Al}, \mathrm{Fe}$ and other components. Spyridakis et al. (1967) further stated that the removal of $\mathrm{K}, \mathrm{Mg}$ and $\mathrm{Fe}$ in biotites by their substitution with $\mathrm{H}_{3} \mathrm{O}$ ions, transformed biotites into kaolinite with a vermiculite stage. Fanning et al. (1989) also stated that the removal of $\mathrm{K}$ from interlayer biotite, transformed it into secondary 2:1 phyllosilicate which is more often vermiculite.

According to Hatton et al. (1987), different tree species produced different deviation linked to their ability to cycle cations and organic compunds which attack minerals. 
Sohet et al. (1988) reported a significant decrease in the amounts of weatherable minerals (F-feldspars, albite, muscovite and 2:1 clay minerals), particularly chlorite under Norway spruce (Picae abies) than beech (Fagus sylvatica). Organic acids from decomposing litters were reported by Egli et al. (2001) to cause decrease in mica content and accelerated its transformation into smectite-like minerals. Similarly, Alekseeva et al. (2010) observed the dissolution of hydro-Al interlayer within the structure of vermiculite under tea plantation, thus transforming vermiculite to chloritized-vermiculite to kaolites and oxides.

Considering the role of vegetation in soil formation and development, it therefore becomes necessary to study the influence of exotic tree species, especially teak (Tectona grandis), on the pedogenetic forms of Fe and $\mathrm{Al}$ and mineralogical properties of basaltic soils in the southern guinea savanna of Nigeria.

\section{MATERIALS AND METHODS Setting of the study Area}

Nimbia Forest Reserve is located in the southern guinea savanna of Nigeria and covers an area of about 2,282.4 hectares. It lies between longitudes $8^{0}$ $30^{\prime \prime}$ and $8^{\circ} 31^{\prime \prime} \mathrm{E}$ and latitudes $9^{\circ} 29^{\prime \prime}$ and $9^{\circ} 30^{\prime \prime} \mathrm{N}$ (Figure 1), with an elevation of about $600 \mathrm{~m}$ about sea level. Nimbia Forest Reserve is located within the Jemma'a platform underlain by igneous and metamorphic rocks. The soils belong to the Nimbia series developed from weathered olivine basalts and classified as Eutropic brown by D'Hoore (1964), while Samndi (2006) classified the soil as Dystrustept and Haplustult respectively. The position of Nimbia with respect to its altitude $(600 \mathrm{~m})$ induces orographic rain with mean annual rainfall of about $1260.11 \mathrm{~mm}$ and mean annual temperature of about $21.7^{\circ} \mathrm{C}$.

\section{Field Studies}

The unpublished semi-detailed soil survey report by Howard (1963) and planting record map were used in preliminary site selection for the study. Areas described as Nimbia clay were investigated under the following planting years, namely 1990 (11years), 1980 (21 years), 1970 (31 years) and 1965 (36 years). A total of 12 pedons were located within the various planting periods with three pedons exposed in each planting period to a depth of at least $160 \mathrm{~cm}$ or to an impenetrable layer, whichever came first. Soil profile site characteristics were described according to USDA soil survey manual (Soil Survey Staff, 1981). In addition, two perpendicular 5-meter transects were laid in North - south and East - West directions in a fallow. Samples were collected from genetic horizons and transects at $0-30$ and $30-60 \mathrm{~cm}$ depths for laboratory analysis.

\section{Laboratory Analysis}

Soil samples from the genetic horizons, 0-30 and 30$60 \mathrm{~cm}$ depths were air-dried and passed through a $2 \mathrm{~mm}$ sieve. Particle size distribution was determined by the hydrometer method (Gee and Bauder, 1986).
Soil $\mathrm{pH}$ was determined in water using a soil to water ratio of 1:2.5 (IITA, 1979). The organic carbon content was determined by wet oxidation method of Walkley - Black as described by Nelson and Sommer (1982). The amorphous forms of $\mathrm{Fe}$ and Al were extracted by the ammonium oxalate techniques (Schwertmann, 1964). Free iron and aluminium oxides were determined according to the methods of Mehra and Jackson (1960), using citrate - bicarbonatedithionite. The Fe in the extracts was determined with atomic absorption spectrophotometry, while Al was determined colorimetrically after the destruction of organic matter as described by Jackson (1958).

The mineralogical analysis was carried out by Differential Thermal Analysis (DTA). The samples were finely ground to $<0.75$ ủm and was transferred into the DTA machine (Eberbach Weston model 301-57). The sample was covered in a furnace and heated. The temperature of the samples and corresponding galvanometer readings were taken at an interval of $20^{\circ} \mathrm{C}$ up to about $1000^{\circ} \mathrm{C}$. The galvanometer readings were plotted against the temperatures. The relative quantity of each clay mineral present was expressed as a function of peak intensity and area. The peaks determined were compared with reference curves and the respective clay minerals identified. Results were subjected to analysis of variance using GENSTAT V package for statistical analysis. Regression and correlation techniques were used to determine relationships between some soil variables.

\section{RESULTS AND DISCUSSION}

\section{Oxalate extractable iron and aluminium oxides}

The oxalate extractable $\mathrm{Fe}\left(\mathrm{Fe}_{\mathrm{ox}}\right)$ mean values slightly increased with plantation age, though not statistically different from those of the fallow, 31 and 36 year old plantations (Table 1). The mean values were significantly lower $(P=0.01)$ in the subsurface horizons and ranged between 0.19 to 0.64 percent. The increase in $\mathrm{Fe}_{\mathrm{ox}}$ with plantation age, is indicated by a significant regression coefficient value $\left(r^{2}=\right.$ $0.7011^{* *}$, not indicated in table). This suggests that higher organic matter under the older plantations might have inhibited the crystallization of Fe (Blume and Schwertmann 1969; Nayak et al. 1999). The oxalate extractable aluminium $\left(\mathrm{Al}_{\mathrm{ox}}\right)$ for both surface and subsurface horizons under the fallow and the various plantation ages ranged between 0.29 and 0.43 and 0.35 to 0.43 percent respectively. The mean value was slightly lower under fallow. Oxalate $\mathrm{Fe}$ and Al values generally decreased with increased profile depth (Table 2), particularly under the older plantations where profiles are deeper, indicating that very small quantises of amorphous $\mathrm{Fe}$ and $\mathrm{Al}$ were translocated. This diminishing contents of $\mathrm{Fe}_{\mathrm{ox}}$ and $\mathrm{Al}_{\mathrm{ox}}$ with depth, may largely be a function of acid complexing $\mathrm{Fe}$ and $\mathrm{Al}$, thus reducing their mobility with depth as observed by Andriesse (1975), that oxalate extract both amorphous hydrous oxides and fulvic complexed Fe. Similar observations were also made by Juo et al, (1974) and Kparmwang (1993). 


\section{Citrate -bicarbonate-dithionite extractable iron and aluminium}

The CBD extractable iron $\left(\mathrm{Fe}_{\mathrm{d}}\right)$ values are generally higher than oxalate extractable Fe oxides for both surface and subsurface horizons indicating the dominance of crystalline Fe over amorphous forms, an observation also made by Kparmwang (1993), Maniyunda (1999) and Raji et al. (2000). The Fe mean values for both horizons ranged from 3.46 to 7.12 percent. The mean values for the underlying horizons were significantly higher $(P=0.05)$, than the overlying horizons and slightly decreased with plantation age, a fact that might be ascribed to the inhibitory property of organic matter on the crystallization of iron. The profile distribution of $\mathrm{Fe}_{\mathrm{d}}$ showed an increase with depth (Table 2), following the trend of clay distribution with argillic horizons recording higher values, suggesting co-migration of
$\mathrm{Fe}_{\mathrm{d}}$ with clay as indicated by a highly significant positive correlation with clay (Table 3 ). This is an indication of the dominance of crystalline form of $\mathrm{Fe}$ resulting from greater pedogenic processes, or insitu weathering (Asanwa, 1973; Pattil and Dosog 1997). The mean values of $\mathrm{Al}_{\mathrm{d}}$ ranged between 1.60 and 3.82 percent, for both surface and subsurface horizons. These values increased irregularly with depth, similar to observation made by Alekseeva et al. (2010) though values were not significantly different from each other. The mean values of $\mathrm{Al}_{\mathrm{ox}}$ and $\mathrm{Al}_{\mathrm{d}}$ were mostly higher than those reported by Kparmwang (1993) on both the Newer and Older Basalts of Nigeria this highlights the fact the intensity of weathering is higher under plantation conditions. This was also corroborated with Zanellis et al. (2007) that the intensity of weathering is higher under plantation.

Table 1: Extractable Iron, Aluminium and Active iron in surface and subsurface horizon in Nimbia Forest Reserve.

\begin{tabular}{|c|c|c|c|c|c|}
\hline $\begin{array}{l}\text { Ages } \\
\text { (years) }\end{array}$ & $\mathbf{F e}_{\text {ox }}$ & $F^{d}$ & $\mathbf{A l}_{\mathrm{ox}}$ & $\mathbf{A l}_{\mathbf{d}}$ & Active - Fe \\
\hline \multicolumn{6}{|c|}{ Surface horizons $(0-30 \mathrm{~cm})$} \\
\hline Fallow & $0.62 \mathrm{a}$ & $3.85 \mathrm{cb}$ & $0.29 c$ & $1.68 \mathrm{ba}$ & $0.16 a$ \\
\hline 11 & $0.39 b$ & $5.97 a$ & $0.43 a$ & $3.82 \mathrm{a}$ & $0.07 b$ \\
\hline 21 & $0.48 \mathrm{ba}$ & $5.68 a$ & $0.43 a$ & $2.64 \mathrm{ba}$ & $0.09 \mathrm{ba}$ \\
\hline 31 & $0.58 \mathrm{a}$ & $4.23 b$ & $0.33 b c$ & $3.19 a$ & $0.14 a$ \\
\hline 36 & $0.66 a$ & $3.46 c$ & $0.41 \mathrm{ba}$ & 3.05a & $0.19 a$ \\
\hline LSD & 0.19 & 1.63 & 0.10 & 2.20 & 0.11 \\
\hline \multicolumn{6}{|c|}{ Subsurface horizons $(30-60 \mathrm{~cm})$} \\
\hline Fallow & $0.19 \mathrm{~b}$ & $4.43 b$ & $0.35 \mathrm{ba}$ & 1.60 & 0.04 \\
\hline 11 & $0.31 \mathrm{ba}$ & $6.54 a$ & $0.43 a$ & 3.60 & 0.05 \\
\hline 21 & $0.40 \mathrm{ba}$ & $7.12 a$ & $0.35 \mathrm{ba}$ & 1.95 & 0.06 \\
\hline 31 & $0.64 \mathrm{ba}$ & $4.43 b$ & $0.35 \mathrm{ba}$ & 1.95 & 0.15 \\
\hline 36 & $0.56 \mathrm{ba}$ & $4.63 b$ & $0.38 \mathrm{ba}$ & 1.68 & 0.12 \\
\hline LSD & 0.46 & 1.49 & 0.11 & 2.9 & 0.30 \\
\hline
\end{tabular}

Means within a column followed by the same letters are not significantly different at $p=0.05$ by Duncans multiple range test.

\section{Active iron and clay dithionite iron ratios}

According to Blume and Schwertmann (1969) and Juo et al. (1974), the ratio of oxalate to dithionite extractable iron $\left(\mathrm{Fe}_{\mathrm{ox}} / \mathrm{Fe}_{\mathrm{d}}\right)$ is referred to as active $\mathrm{Fe}$ ratio. The ratio is used to determine the degree of aging or crystalline form of free iron oxides which is a major pedogenic process. The mean values of active $\mathrm{Fe}$ in the surface horizons were lower $(0.01$ to 0.02$)$ than those reported by Otilio el at. (2002) on basaltic andesite. This suggests the dominance of crystalline Fe oxides, views expressed by Blume and Schwertmann (1969) and Aniku and Singer (1990). The transformation of amorphous Fe to crystalline form indicates an advanced stage of weathering. For the underlying horizons, active $\mathrm{Fe}$ values were significantly lower $(P=0.01)$ than those of the overlying horizons, though the range was similar $(0.01$ to 0.02 ). This suggests a higher proportion of $\mathrm{Fe}$ oxides were more in the crystalline form (Juo et al. 1974; Lekwa and Whiteside 1986). Generally active Fe ratio decreased irregularly with profile depth (Table 2 ) irrespective of plantation age, implying higher degree of weathering the subsoil horizons. The active Fe ratios in both surface and subsurface horizons slightly decreased with plantation age, thus suggesting the transformation of iron into less active forms under the older plantations (Nayak et al, 1999).

\section{Mineralogical properties}

According to Mackenzie (1957) and Plante et al.(2009), Differential Thermal Analysis (DTA) permits a number of valid mineralogical assessments to be made. The differential thermograms of the soils studies are presented in Figures 2 to 6, the minerals identified in both surface and subsurface horizons are shown in Table 4. Thermograms of the soils under the fallow, showed moderate and strong exothermic and endothermic peaks at 580 and $700^{\circ} \mathrm{C}$, followed by other weaker peaks at 350 and $380^{\circ} \mathrm{C}$. These peaks indicated the presences of biotite, amphibole, kaolinite and magnetite. Weaker exothermic peaks between 500 and $900^{\circ} \mathrm{C}$ indicated the presences of amphibole, biotite, montmorillonite and magnetite in the subsurface horizons under the fallow. 
The dominance of these weatherable minerals in both horizons implies the soils under the fallow are moderately weathered. Surface horizons under 11 year old plantation, showed strong exothermic peaks at 500,700 and $800^{\circ} \mathrm{C}$, with weak peaks at 600 and $800^{\circ} \mathrm{C}$. These peaks identified the dominance of biotite and magnetite with amphibole being the least mineral identified. These are indices of early stages of basaltic weathering. It would be remembered that nutrient uptake have been reported by Nettleton et al. (1973) to be an important mechanism in the transformation of biotite. Peaks were generally weak in the subsurface horizons, with a strong endothermic peak at $800^{\circ} \mathrm{C}$ indicating the dominance of magnetite and montmorillonite over chlorite and kaolinite. The presences of these secondary minerals implied an increased weathering compared with the fallow. This observation is also corroborated by Ojanuga (1973), who reported that the first stage of biotite weathering is the dissolution of octahedral Fe and $\mathrm{Mg}$, followed by the loss of $\mathrm{K}$, thus giving rise to montmorillonite. Magnetite $\left(580^{\circ} \mathrm{C}\right)$, montmorillonite $\left(850^{\circ} \mathrm{C}\right.$ exo $)$ and kaolinite (700 and $800^{\circ} \mathrm{C}$ endo) dominated the mineralogy of the surface horizons under 21 year old plantation, traces of amphiboles and biotites were also observed in both horizons. The dominance of montmorillonite, kaolinite and magnetite are indications of increased level of weathering with aging plantation.

Table 2: Extractable iron and aluminum and their ratios of pedons under Teak plantation in Nimbia Forest Reserve.

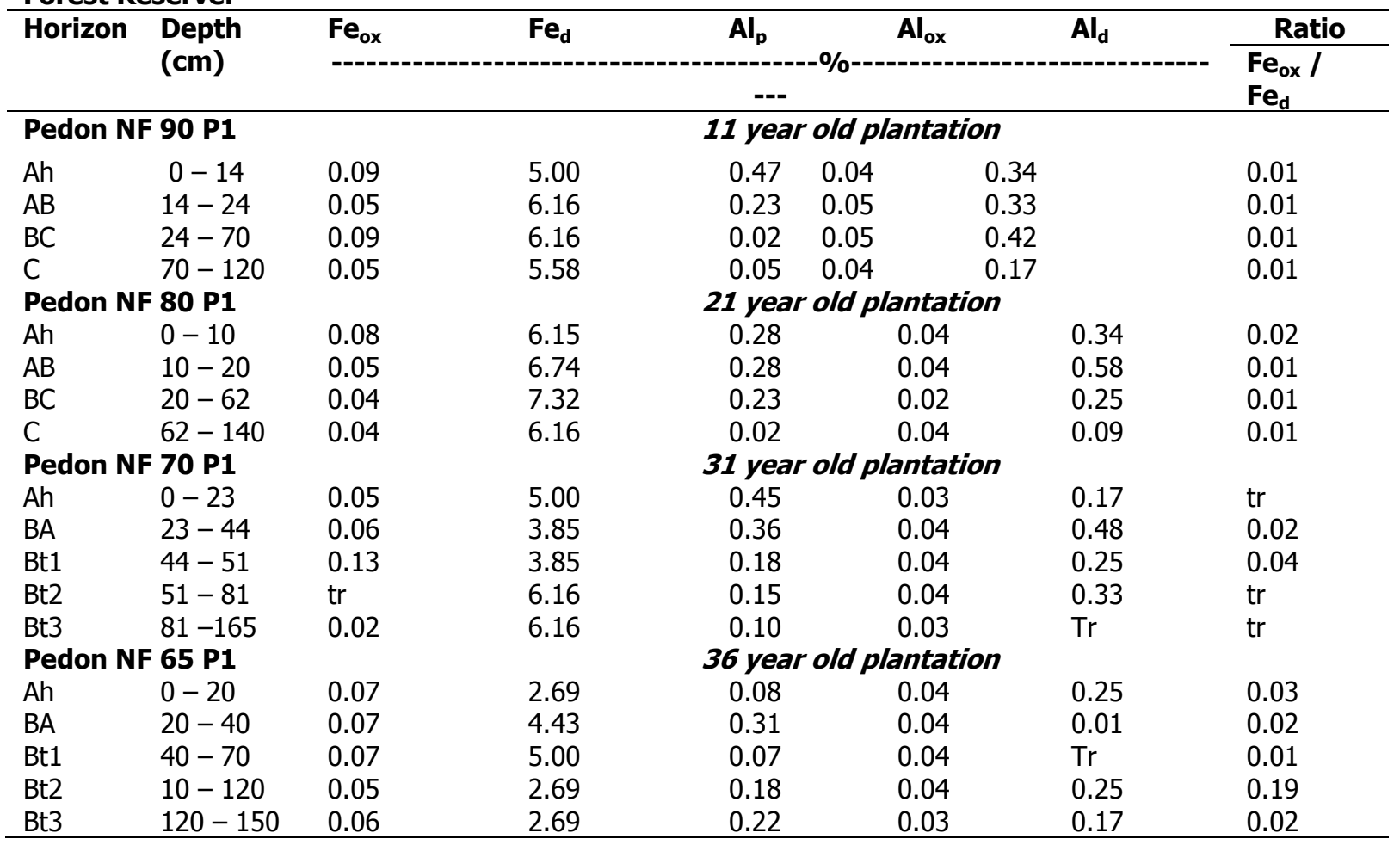

Table 3: Correlation coefficient matrix of pedogenic oxides of iron and aluminium and related soil properties of profiles under Teak plantation in Nimbia Forest Reserve

\begin{tabular}{|c|c|c|c|c|c|c|c|c|}
\hline & Sand & Clay & pH & Org. C & $\mathrm{Fe}_{\mathrm{ox}}$ & $\mathrm{Fe}_{\mathrm{d}}$ & $\mathbf{A l}_{\mathrm{ox}}$ & $\mathbf{A l}_{\mathrm{d}}$ \\
\hline Sand & 1.000 & & & & & & & \\
\hline Clay & $-0.530 * *$ & 1.000 & & & & & & \\
\hline pH & $0.526 * *$ & 0.222 & 1.000 & & & & & \\
\hline Org. C & $0.575^{* *}$ & $-0.404 * *$ & $0.394 * *$ & 1.000 & & & & \\
\hline $\mathrm{Fe}_{\mathrm{ox}}$ & 0.114 & -0.143 & 0.023 & 0.133 & 1.000 & & & \\
\hline $\mathrm{Fe}_{\mathrm{d}}$ & -0.257 & $-0.445^{* *}$ & 0.157 & 0.132 & -0.124 & 1.000 & & \\
\hline $\mathbf{A l}_{\mathrm{ox}}$ & $0.298^{*}$ & -0.035 & $0.336 *$ & $0.266 *$ & 0.010 & 0.017 & 1.000 & \\
\hline$A \mathbf{l}_{d}$ & 0.047 & -0.093 & 0.146 & $0.318^{*}$ & 0.059 & 0.083 & 0.202 & 1.000 \\
\hline
\end{tabular}

Significant level $=* \mathrm{P}<0.05, \quad * * \mathrm{P}<0.01$ 


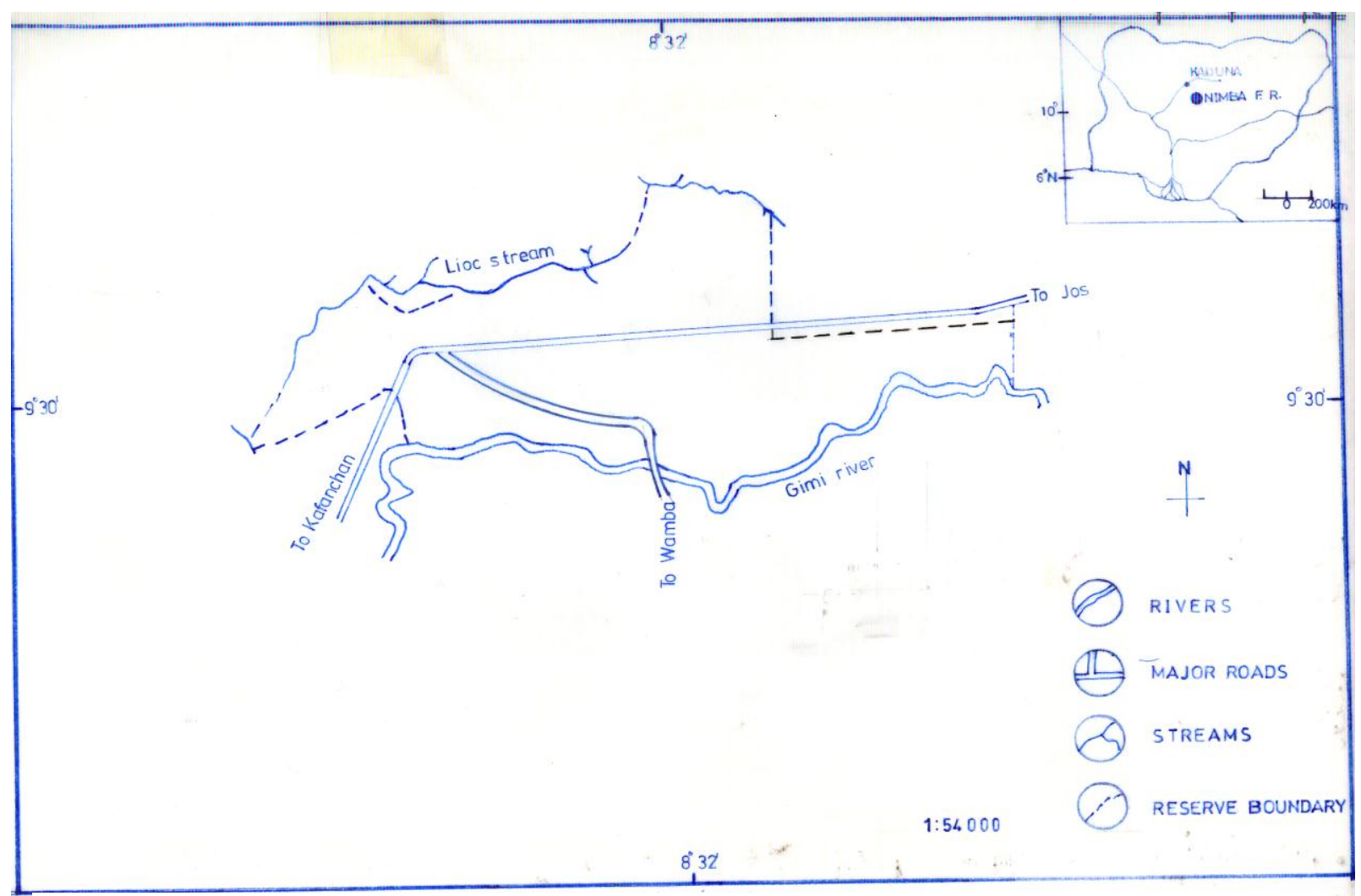

Figure 1: Map of Nimbia Forest Reserve Showing Drainage and Boundary (Insert Map

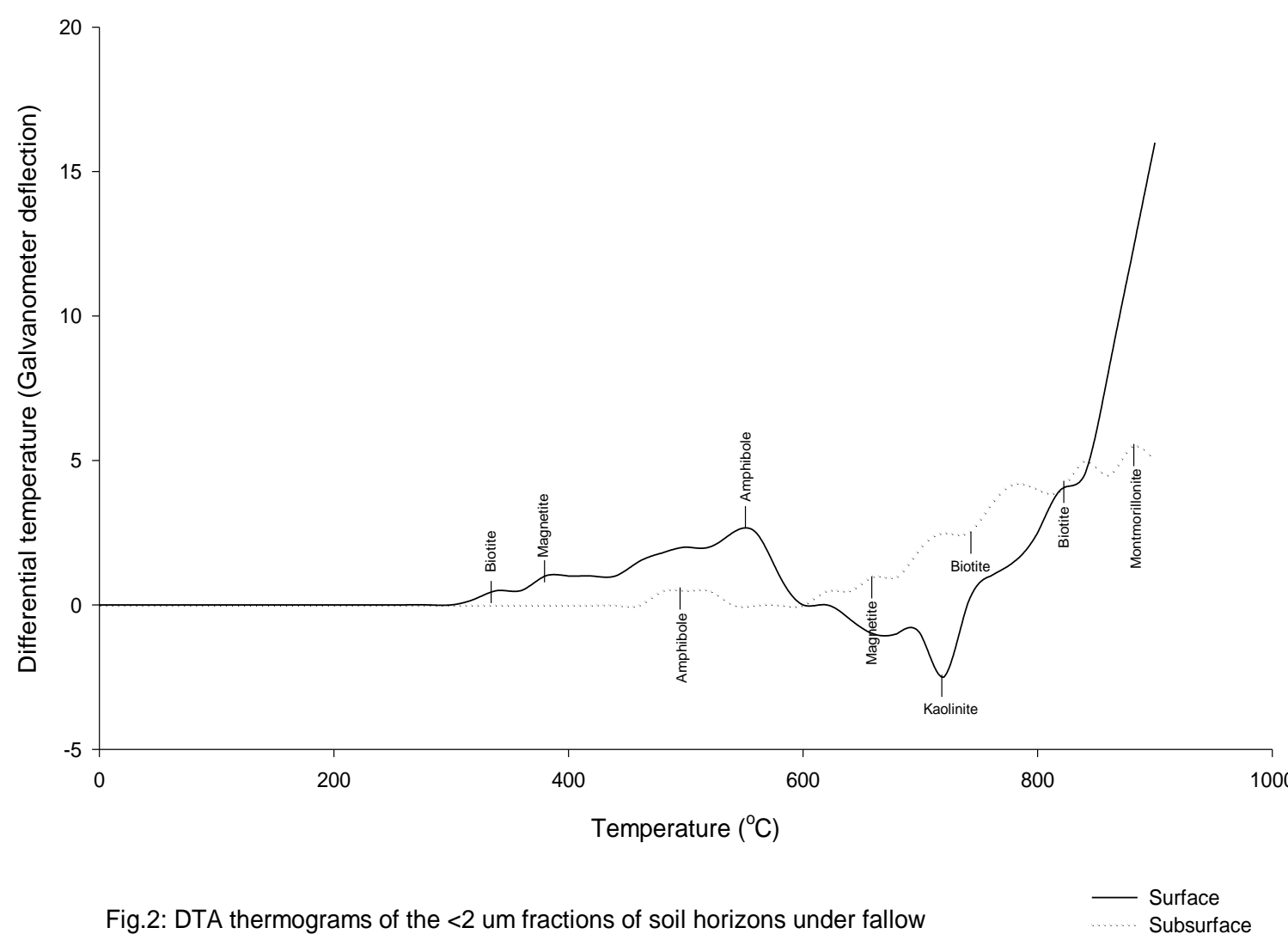




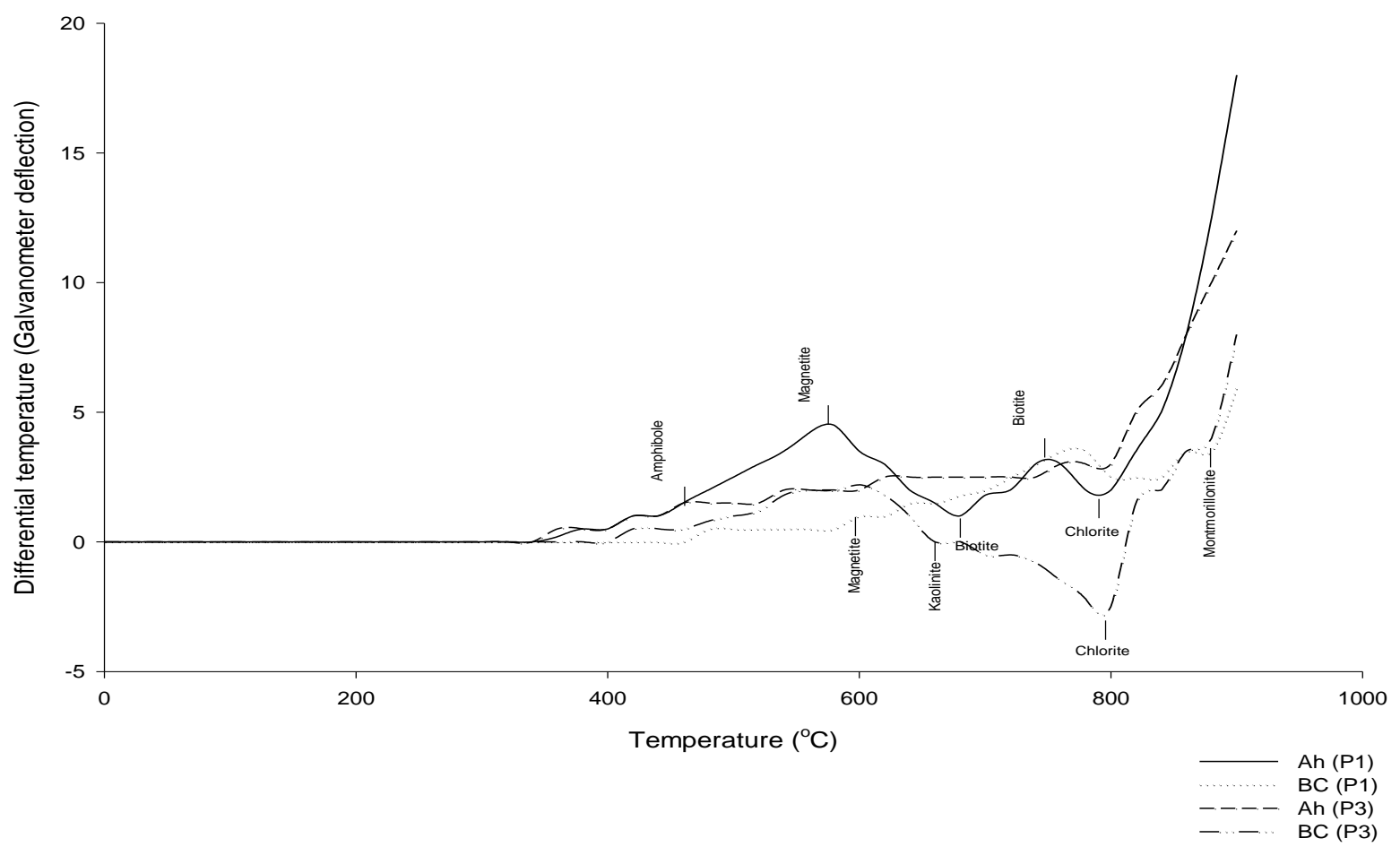

Fig. 3: DTA thermograms of the <2um fractions of soil horizons under 11 year old plantation

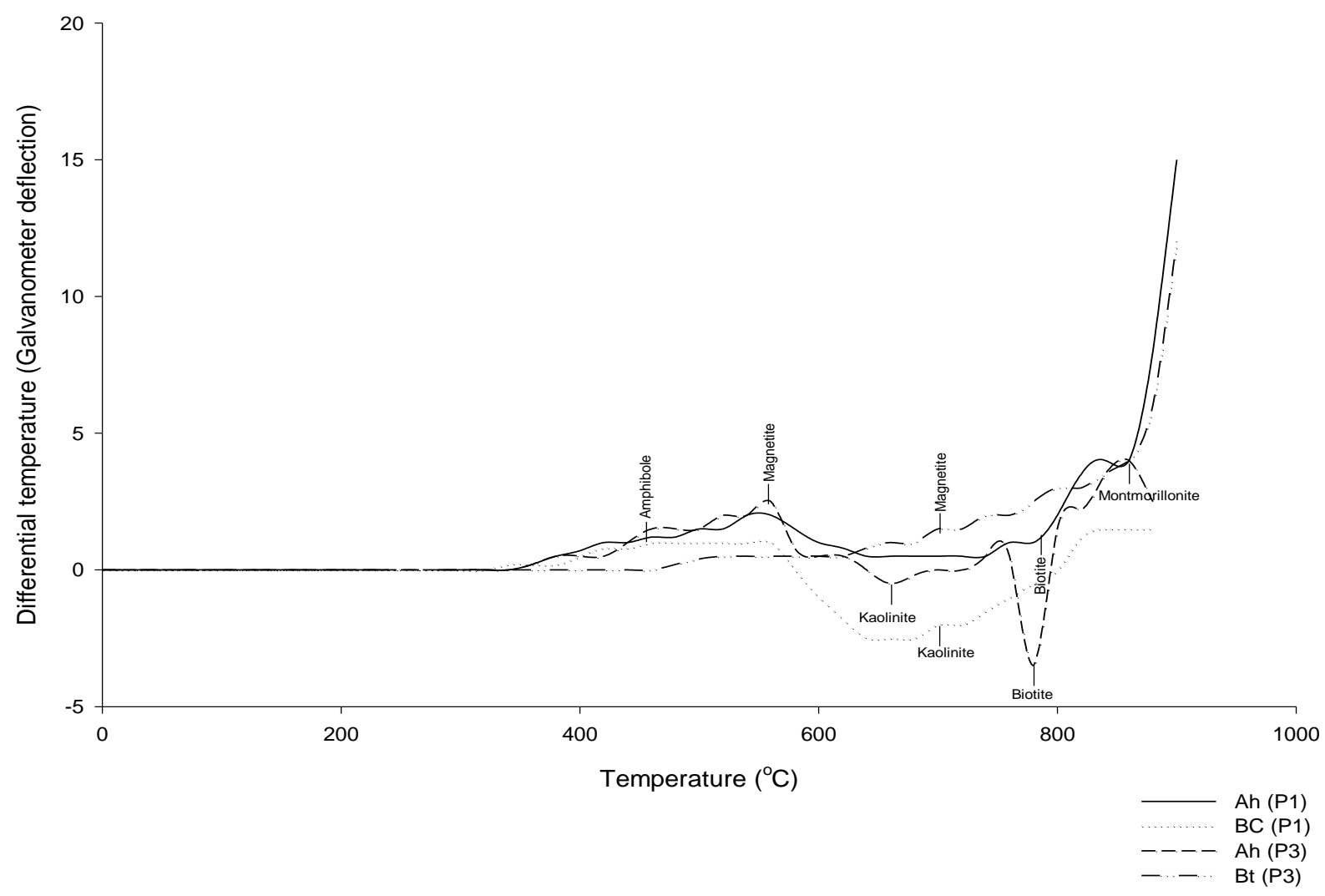

Fig. 4: DTA thermograms of the $<2$ um fractions of the soil horizons under 21 year old plantation 


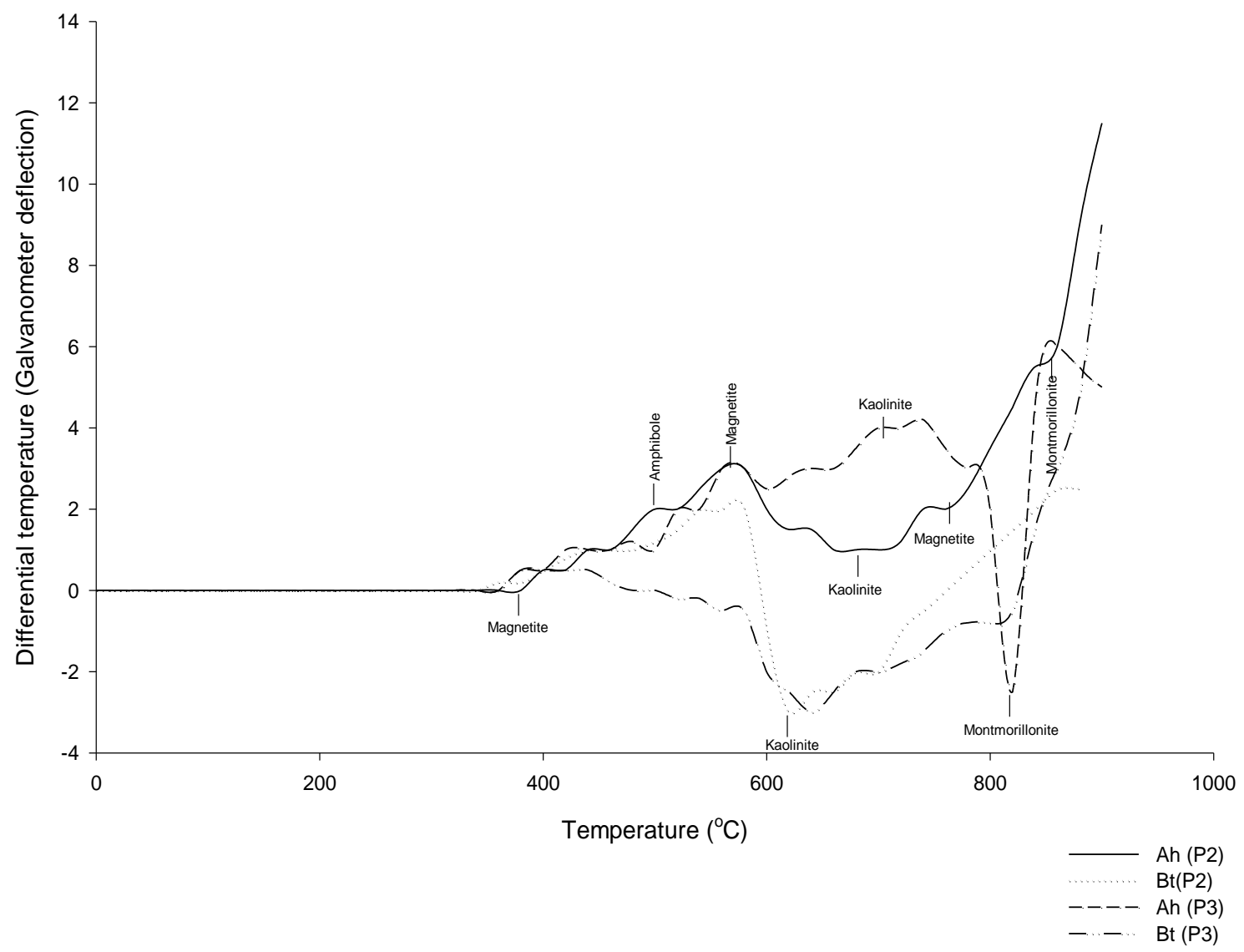

Fig. 5: DTA thermograms of the $<2 u m$ fractions of soil horizons under 31 year old plantation

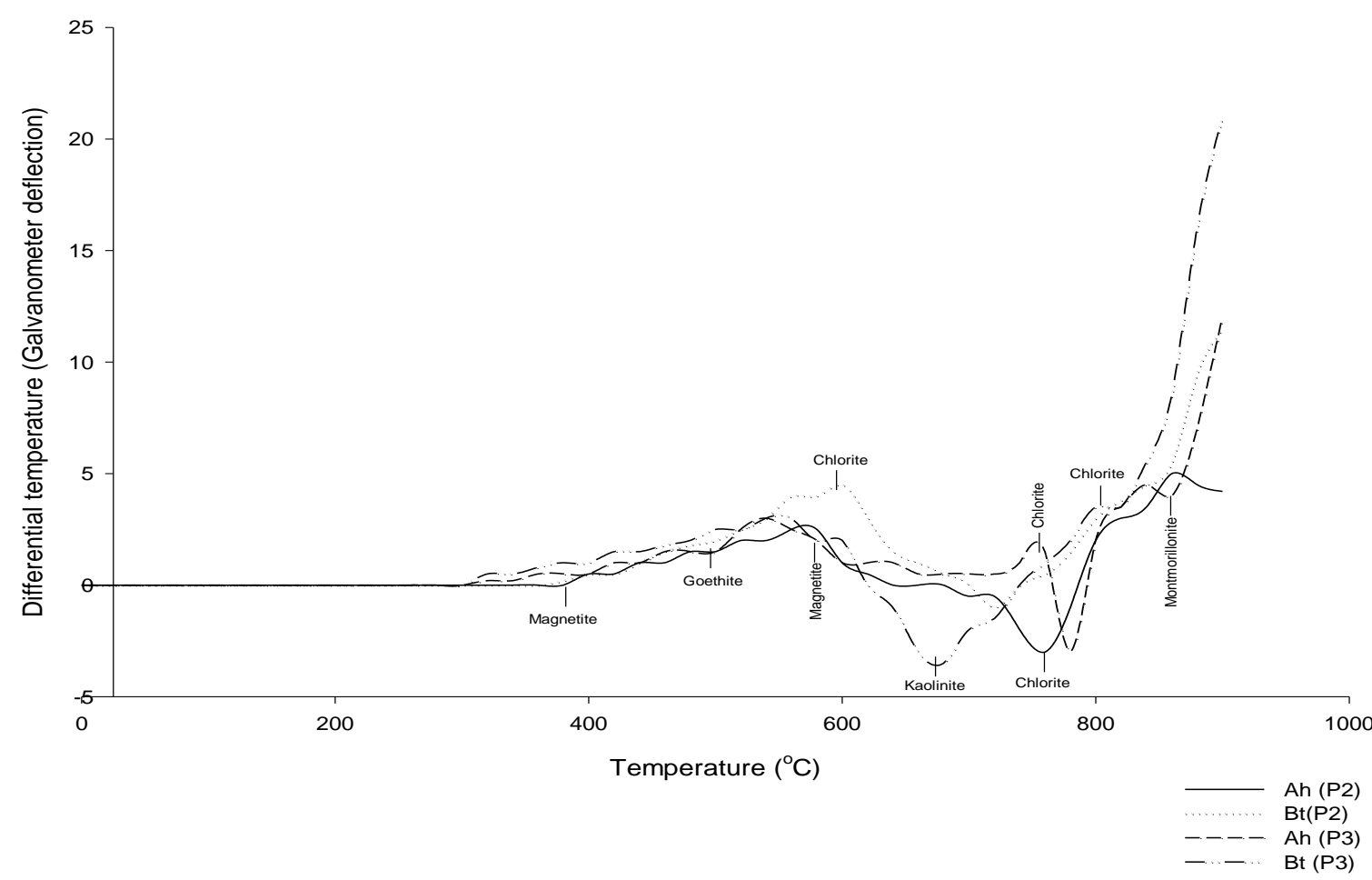

Fig.6: DTA thermograms of the $<2$ um fractions soil horizons under 36 year old plantation 
Bajopas Volume 5 Number 1 June, 2012

Table 4: Differential thermal analysis of surface and subsurface horizons under the fallow and the various plantation ages.

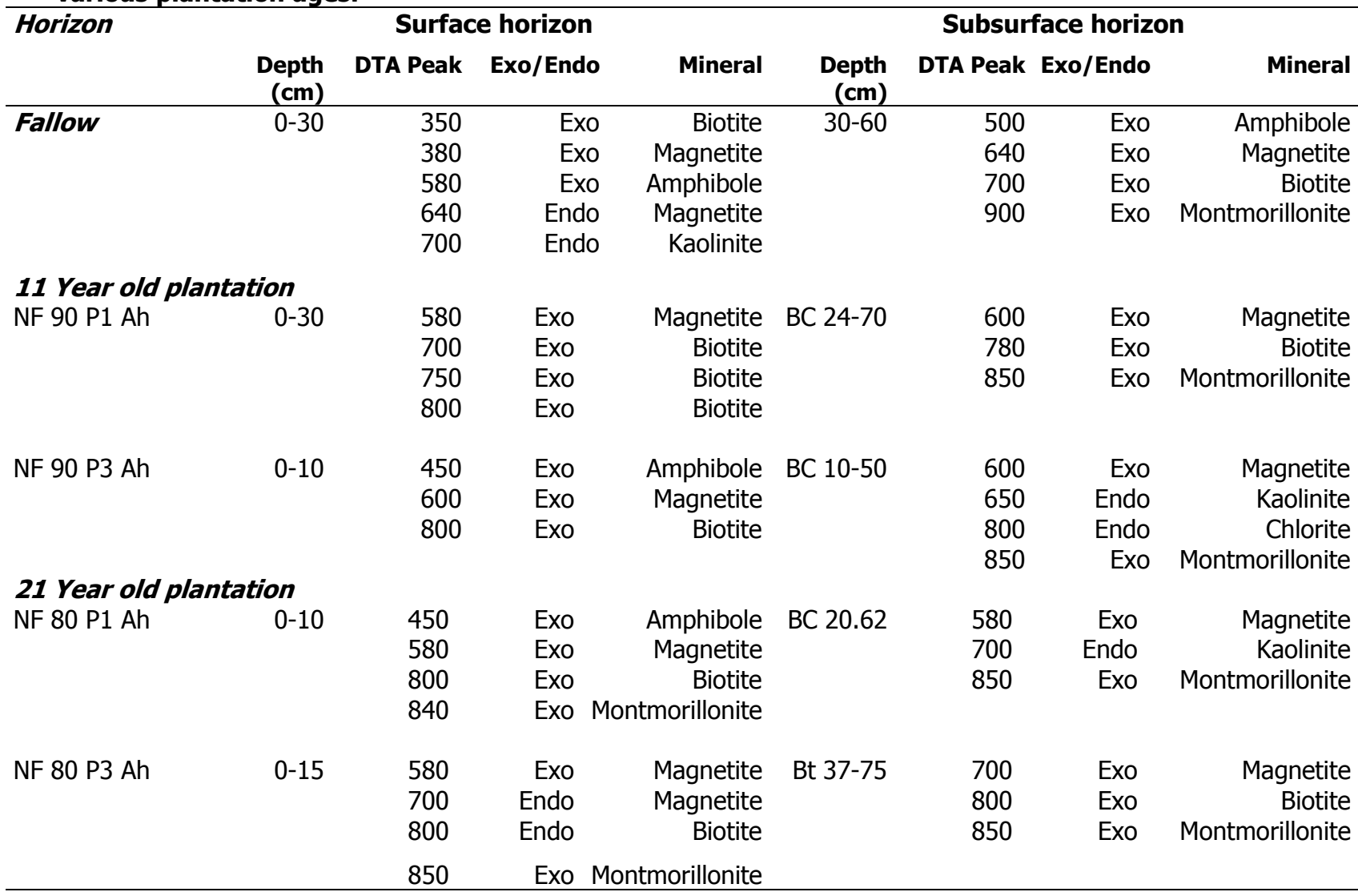

Table 4 (Contd): Differential thermal analysis of surface and subsurface horizons under the fallow and the various plantation ages.

\begin{tabular}{|c|c|c|c|c|c|c|c|c|}
\hline \multirow[t]{2}{*}{ Horizon } & \multicolumn{4}{|c|}{ Surface horizon } & \multicolumn{4}{|c|}{ Subsurface horizon } \\
\hline & $\begin{array}{r}\text { Depth } \\
(\mathrm{cm}) \\
\end{array}$ & DTA Peak & Exo/Endo & Mineral & $\begin{array}{r}\text { Depth } \\
(\mathbf{c m}) \\
\end{array}$ & $\begin{array}{r}\text { DTA } \\
\text { Peak }\end{array}$ & $\begin{array}{r}\text { Exo/End } \\
0 \\
\end{array}$ & Mineral \\
\hline \multicolumn{9}{|c|}{31 Year old plantation } \\
\hline \multirow[t]{6}{*}{ NF 70 P2 Ah } & $0-17$ & 500 & Exo & Amphibole & Bt $36-65$ & 600 & Exo & Magnetite \\
\hline & & 580 & Exo & Magnetite & & 610 & Endo & Kaolinite \\
\hline & & 680 & Endo & Haematite & & 680 & Endo & Haematite \\
\hline & & 700 & Exo & Magnetite & & 700 & Exo & Kaolinite \\
\hline & & 780 & Exo & Magnetite & & 850 & & Montmorillonite \\
\hline & & 850 & Exo & Montmorillonite & & & & \\
\hline \multirow[t]{6}{*}{ NF 70 P3 Ah } & $0-19$ & 500 & Exo & Amphibole & Bt $45-77$ & 580 & Endo & Chlorite \\
\hline & & 580 & Exo & Magnetite & & 620 & Endo & Kaolinite \\
\hline & & 680 & Endo & Haematite & & 700 & Endo & Kaolinite \\
\hline & & 700 & Exo & Magnetite & & 800 & Endo & Chlorite \\
\hline & & 820 & Endo & Montmorillonite & & & & \\
\hline & & 850 & Exo & Montmorillonite & & & & \\
\hline \multicolumn{9}{|c|}{36 Year old plantation } \\
\hline \multirow[t]{5}{*}{ NF 65 P2 Ah } & $0-12$ & 580 & Exo & Magnetite & Bt 36-77 & 380 & Endo & Goethite \\
\hline & & 680 & Endo & Haematite & & 600 & Exo & Magnetite \\
\hline & & 700 & Endo & Chlorite & & 680 & Endo & Haematite \\
\hline & & 780 & Endo & Chlorite & & 700 & Endo & Kaolinite \\
\hline & & 850 & Exo & Montmorillonite & & 800 & Exo & Biotite \\
\hline \multirow[t]{4}{*}{ NF 65 P3 Ah } & $0-18$ & 500 & Exo & Amphibole & Bt $30-62$ & 507 & Exo & Goethite \\
\hline & & 780 & Exo & Chlorite & & 600 & Exo & Chlorite \\
\hline & & 800 & Endo & Chlorite & & 620 & Endo & Kaolinite \\
\hline & & 900 & Exo & Montmorillonite & & $\begin{array}{l}700 \\
850\end{array}$ & $\begin{array}{r}\text { Endo } \\
\text { Exo } \\
\end{array}$ & $\begin{array}{r}\text { Kaolinite } \\
\text { Montmorillonite }\end{array}$ \\
\hline
\end{tabular}




\section{CONCLUSION}

The effects of Tectona grandis on soil properties showed high values of $\mathrm{Fe}_{\mathrm{ox}}$ and $\mathrm{Al}_{\mathrm{d}}$, which implied an increased vigour in weathering. Active Fe values were lower than 1 for the respective plantation ages and profile depths. This suggests that as plantation becomes older, crystalline forms of $\mathrm{Fe}$ and $\mathrm{Al}$ increased, indicating an evidence of increased weathering intensity. The general trend of surface mineralogy under the fallow and the various plantation ages indicated that under the fallow, magnetite was the dominant mineral, biotite montmorillonite and chlorite were the dominant

\section{REFERENCES}

Alekseeva, T., Alekseeva A., Ren - Kou Xu, An - Zhen Zhao and Kalinin P. (2010): Effect of soil acidification induced by tea plantation on chemical and mineralogical properties of Alfisols in eastern China. Environ. Geochem. Health. DOI 10/007/s/0653 - $9327-5$.

Alexander, E. B. (1974): Extractable iron in relation to soil ash on terraces along the Truckee River. Soil Sci. Am. Proc. 38:121-124

Andrew, A. P. and John G. 1988. Soluble Organics from Forest litters and their roles in metal dissolution. Soil Sci. Soc. Am. J. 52:265 - 271

Andriesse, J. P. (1975): Characteristics and formation of so -called Red-yellow podzolic soils in the Humid Tropics (Sarawak-malaysia). Department of Agricultural Research of the Koyal Tropical Amsterdam Communication. 66 $188 \mathrm{pp}$.

Aniku, R.F. Jacob and Singer, Michael. (1990): Pedongenic iron oxide trends in a marine terrace chronosequence. Soil Sci. Soc. Am. J. 54:147-122

Asanwa, G. K. (1973): Particle size and free iron distribution in some latosols and ground water laterites of Ghana. Geoderma 10:285-297.

Balagopalan, M. and Rugmini. P. (1989): Soil characteristic along a transect as influenced by Teak plantation in Kerala India The Malaysian Forester. Vol. 52 No. 2: 68-71

Blume, H. P. and Schwertmann U. (1969): Genetic evaluation of profile distribution of aluminimum iron and manganese oxides. Soil Sci. Am Proc. 33: 438-444.

Courchesne, I. and Gobran R. (1997): Mineralogical variations of bulk and rhzosphere soils from a Norway spruce stand. Soil Sci. Soc Am. J. 61: 1245-1249.

D'Hoore, J. L. (1964): Soil Map of Africa. Scale 1: 500,000. Explanatory monograph C.C. T Lagos. 205.

Egli. M., Mirabella A. and Fitze P. (2001): Clay mineral transformations in soils affected by fluorine depletion of organic matter within a time span of 24 years. Geoderma 103: 307 - 334.

Fanning, D. S., Keramidas V. Z. and El-Doloky (1989): Mica. In J. B. Dixon and S. B. Weed (eds). Minerals in Soil Environment $2^{\text {nd }}$ SSSA Madison W.I. 551-634. minerals under 11, 21, 31 and 36 year old plantations. For the subsurface horizons, biotite was the dominant mineral under the fallow and 11 year old plantation, with montmorillonite being the dominant clay mineral under 21 and 31 year old plantations. Kaolinite was the dominant clay mineral obtained under oldest plantation, thereby implying that kaolinization increases as plantation becomes older as a result of increased level of weathering. The presence of high contents of crystalline forms of Fe, Al, kaolinites and traces of haematite and goethite deducts that Tectona grandis deteriorates soil properties with time.

Gee, W. G. and Bauder Y. N. (1986): Particle size analysis. In Klute A. (ed). Methods of soil Analysis. Part 1 Agron. Madison W. I. USA 381 - 411pp.

Hatton, A. J., Ranger M., Robert C. and Bonnad P. (1987): Weathering of mica induced In four acidic forest soils. Journal of Soil Sci. Soc. 38: 179-190.

Howard, W. J. (1963): Jemma'a Nimbia Forest Reserve. Report on vegetation and sites types. $14 \mathrm{pp}$.

Huang, W. H. and Keller W. D. (1970): Dissolution of rock-forming silicate minerals in organic acids. Am. Mineralogy. 55: 2070-2094

IITA, (1979): Selected methods for soil and plant Analysis. International institute for Tropical Agriculture. Manual series No. 1.

Jackson, M. L. (1958): Soil Chemical Analysis. Prientice Hall inc. Engle wood Cliffs New Hersey 297 - 303

Juo, A.S.R. Moorman, F. and Maduakar R. (1974): Forms and pedogenic distribution of extractable iron, and aluminium in selected soils of Nigeria. Geoderma. 11:167-179.

Kodama H. and Schnitzer M. (1976): The dissolution of micas by fulvic acid. Geoderma. 15: 381391.

Kparmwang, T. (1993): Characterization and classification of basaltic soils in the Northern Guinea Savanna zone of Nigeria. Unpublished PhD. Thesis Ahmadu Bello University Zaria 176 pp.

Lekwa, A. and Whiteside E. P. (1986): Coastal Plain soils of eastern Nigeria. II Forms of extractable iron, aluminum and phosphorus. Soil Sci. Am. J. $50.160-166$.

Mackenzie, R. C. (1957): Differential thermal investigation of clays. Mineralogical society of London. 1-22

Maniyunda, L. M. (1999): Pedogenesis on loess and Basement complex rock of Funtua Nigeria. Unpublished Msc. Thesis Ahmadu Bello University Zaria. 107pp.

Mckeaque, J. A. (ed) (1978): Manual of soil sampling and methods of analysis. Candian Soc. of Soil Sci. Ottawa.

Mckeaque, J. A., Brydon J. E. and Miles N. M. (1971): Differentiation of forms of extractable iron and aluminium in soils. Soil Sci. of Soil Sci. Am. Proc. 35:303 -306. 
Mehra, O. P. and Jackson M. L. (1960): Iron oxide removal from soils and clays by a dithionite citra system buffered with $\mathrm{Na}$ bicarbonate. Clays Clay miner. 5: 317-327.

Nayak D. C., Dipak S. Das K. and Chetterjee .R. (1999): Studies on pedogenesis in a soil chronosequence in west Bengal. Journal of the Indian Soc. of Soil Sci. vol. 47: No. 2322 328.

Nelson, D. W. and Sommers L. E. (1982): Organic carbon. In page A. L. (ed). Methods of Soil Analysis. Part 2. Agron. Mongr. 9. Madison 570-571.

Nettleton, W. D., Nelson R. E. and Flach K. W. (1973): Formation of mica in surface horizons of dry land soils. Soil Sci. Soc Am Pro. 37: 473478.

Ojanuga, A. G. (1973): Weathering of biotite in soils of humid tropical climate. Soil Sci. Soc. Am. Proc. Vol. 37: 644-646.

Otilio, A, Misael C. and Enrique C.(2002): Distribution of $\mathrm{Fe}, \mathrm{Al}$ and $\mathrm{Si}$ oxides in hardened horizons of volcanic sources. _Agrociencia vol. 36 No. 4, 401-409.

Pattil, P. L. and Dosog G. S. (1997): Genesis of iron oxide concretions in Oxisols, Ultisolsand Alfisols of North Karnataka. Journal of the Indian Soc. of Soil Sci, vol. 45 No. 4 778-781.

Phillips, D. J., Alice V. T. and Daniel A. M. (2008): Weathering and vegetation effects in early stages of soil formation. Catena 72: $21-28$.

Plante., A. F., Fernandez J. M. and Leifed. (2009): Application of thermal analysis techniques in soil science. Geoderma 153: $1-10$.

Raji, B. A. Esu, I. E. and Chude, V. O. (2000): Status and profile distribution of free oxide in Haplustults and Quartzipsamments developed on ancient dune in N. W. Nigeria. Samaru Journal of Agric. Res. 16:1 -11.

Samndi, A. M. (2006): An Evaluation of Soil Properties and Development under Teak (Tectona grandis) Plantation of Various ages in Southern Guinea Savanna of Nigeria. Unpublish PhD dissertatation, Ahmadu Bello Univer. Zaria Nigeria.
Schwertmann, U. (1964): The Differentiation of iron oxide in soils by a photochemical extraction with acid ammonium oxalate. $Z$. Planzenernaehr, Dueng. Bodenkd. 105: 194 202

Sohet, K., Herbauts J. and Gruber W. 1988. Changes caused by Norway spruce in Ochreous brown earth assessed by the isoquarzt method. Journal of Soil Sci. 39: 549-561.

Soil Survey Staff, (1981): Examination and Description of Soil in the field. In Soil Survey Manual USDA Agric. Hand book 18 US Govt Printing Office Washington DC.

Spyridakis, D. E., Chesters C. and Wilde S. A. (1967): Kaolinization of biotite as a result of coniferous and deciduous seedling growth. Soil Sci. Soc. Am.Pro. 31: 203-207.

Tan, K. H. (1980): The release of Silicon, aluminium and potassium during decomposition of soil minerials by humic acid. Soil Sci. vol. 129 No. I: $5-11$.

Zanelli, R., Markus E., Aldo M., Daniele G. and Mustapha A. (2007): Vegetation effects on pedogenetic forms of $\mathrm{Fe}, \mathrm{Al}$ and $\mathrm{Si}$ and on clay minerals in soils in southern Switzerland and northern Italy. Geoderma, 141: 119 - 129 